\title{
PENGARUH KEPEMIMPINAN, KUALITAS SDM, DAN BUDAYA ORGANISASI TERHADAP OPTIMALISASI KINERJA PEGAWAI DI PERPUSTAKAAN NASIONAL RI JAKARTA
}

\author{
(Studi Tentang Kepemimpinan, Kualitas SDM Dan Budaya Organisasi Terhadap Optimalisasi \\ Kinerja Pegawai Perpustakaan Nasional RI Jakarta)
}

Diana Toyang', Nunung Prajarto ${ }^{2}$

\begin{abstract}
Labor work performance provides the succers of organization. At the National Library in Jakarta, the labor work performance. can be traced from the support of the leadership, human resources quatity, and organization culture. The problem is to what extent the three factors influence on the work performance.

This siudy focuses on the influence of leadership, quality of human resources and organization culture to the optimalization of officers performance. The research was conducted in the National Library of Indonesia in Jakarta in 2006. A survey with descriptive analysis and correlation analysis of product moment was applied. This includes 120 respondents of population amount counted 693 people and produces statistically positive and significant impacts of the independent variables on the officer performances. After testing the correlation by using double regression at the $95 \%$ level of trust, it is found that Leadership $\left(X_{1}\right)$ is $13,4 \%, Q u a l i t y$ of Human Resource $\left(X_{2}\right)$ equals to $14,6 \%$ and Culture of Organization $\left(X_{3}\right) 16,7 \%$ to variable tied Optimalization Officer Performance $(Y)$ at 10,4 \%. The influence at a time variable of $X_{l}, X_{2}, X_{3}$ to Y pass coefficient of regresi $F_{\text {counsed }}$ equals to $6.5 \%$.

The result of the study indicates that each independent variables $\left(X_{1}, X_{2}, X_{3}\right)$ has statistically positive and significant effect on dependent variables tied (Y). This applied to all respondents worked at the National Library of the Republic of Indonesia.
\end{abstract}

Key words : Leadership, quality of human resource, culture organizational, and of labor work performance.

\begin{abstract}
ABSTRAK
Labor work performance provides the succers of organization. At the National Library in Jakarta, the labor work performance can be traced from the support of the leadership, human resources quality, and organization culture. The problem is to what extent the three factors influence on the work performance.

This study focuses on the influence of leadership, quality of human resources and organization culture to the optimalization of officers performance. The research was conducted in the National Library of Indonesia in Jakarta in 2006. A survey with descriptive analysis and correlation analysis of product moment was applied. This includes 120 respondents of population amount counted 693 people and produces statistically positive and significant impacts of the independent variables on the officer performances. After testing the correlation by using double regression at the $9.5 \%$ level of trust, it is found that Leadership $\left(X_{1}\right)$ is $13,4 \%, Q u a l i t y$ of Human Resource $\left(X_{2}\right)$ equals to $14,6 \%$ and Culture of Organization $\left(X_{3}\right) 16,7 \%$ to variable tied Optimalization Officer Performance $(Y)$ at 10,4 $\%$. The influence at a time variable of $X_{1}, X_{2}, X_{3}$ io Y pass coefficient of regresi $F_{\text {rounted }}$ equals to $65 \%$.

The result of the study indicates that each independent variables $\left(X_{1}, X_{2}, X_{3}\right)$ has statistically positive and significant effect on dependent variables tied $(Y)$. This applied to all respondents worked at the Narional Library of the Republic of Indone sia.
\end{abstract}

Kata Kunci: Kepemimpinan, Kualitas SDM, Budaya Organisasi, Kinerja

${ }^{1}$ Perpustakaan Nasional RI., Jakarta

${ }^{2}$ Fakultas Ilmu Sosial dan Politik Universitas Gadjah Mada, Yogyakarta 


\section{PENDAHULUAN}

\section{A. Latar Belakang Masalah}

Perkembangan ilmu pengetahuan dan teknologi yang sangat pesat mensyaratkan setiap bangsa untuk memiliki daya saing yang kuat. Untuk menghadapi persaingan akibat perubahan yang semakin cepat maka diperlukan manusia yang memiliki kemampuan yang profesional dalam pembangunan di seluruh aspek kehidupan.

Perpustakaan sebagai salah satu sumber informasi, ilmu pengetahuan, teknologi, seni dan budaya, menduduki posisi yang sangat strategis, ekonomis dan demokratis sebagai upaya mencerdaskan kehidupan bangsa, serta sarana pelaksanaan konsep belajar mandiri sepanjang hayat bagi setiap individu.

Untuk melakukan tugas pelayanan informasi di Perpustakaan diperlukan pegawai yang memiliki kompetensi yang profesional dan berkualitas dalam menjalankan tugas pekerjaannya, sehingga diharapkan mampu merespon aspirasi publik ke dalam kegiatan dan program organisasi dan melahirkan inovasi baru yang bertujuan untuk mempermudah memenuhi kebutuhan pengguna informasi. Selain itu diharapkan mampu menghadapi berbagai tantangan perubahan sebagai dampak perkembangan ilmu pengetahuan dan teknologi.

Untuk menguasai perubahan di dalam sebuah organisasi, SDM merupakan aset utama yang tidak ternilai hargany a karena dapat memberikan kontribusi yang berarti kepada satuan kerja secara efektif dan efisien, produktif dan kompetitif. Oleh karena itu untuk memperoleh, mengembangkan, memelihara dan mengoptimalkan kinerja pegawai merupakan salah satu faktor yang perlu mendapat perhatian agar tuntutan adanya kemampuan pegawai pemerintahan yang profesional dan berkualitas sebagaimana diatur dalam Undang-Undang Nomor 43 Tahun 1999 tentang
Perubahan Atas Undang-Undang Nomor 8 Tahun 1974 tentang Pokok-pokok Kepegawaian dalam menjalankan tugas pekerjaannya dapat diwujudkan.

Rendahnya kinerja pegawai merupakan suatu fenomena yang sering terjadi dilingkungan organisasi pemerintahan. Kondisi ini merupakan persoalan besar yang dirasakan oleh masyarakat yang dilayani.

Manajemen merupakan proses usaha pencapaian tujuan melalui kerjasama dengan orang lain. Artinya keberhasilan organisasi sangat tergantung pada faktor kepemimpinan dalam menggerakkan sumber daya yang dimiliki baik sumber daya manusia (SDM) maupun sarana dan prasarana dalam kegiatan sehari-hari.

Untuk mencapai tujuan tersebut, maka pembinaan dan pengembangan pegawai perlu dilakukan tidak hanya meliputi pembinaan dan pengembangan aspek teknis saja, melainkan juga melalui pembinaan terhadap aspek-aspek psikologis seperti pengembangan serta peningkatan budaya organisasi yang mempunyai peranan yang strategis dalam menumbuhkan nilai-nilai dan standar-standar organisasi dan mendorong meningkatkan optimalisasi kinerja pegawai baik dalam jangka pendek maupun jangka panjang.

Selanjutnya untuk dapat menghasilkan kinerja secara optimal, diperlukan SDM yang profesional. Berhasilnya suatu program kerja antara lain karena dapat dipenuhinya prinsip-prinsip umum manajemen yang mencakup : pembagian kerja, wewenang dan tanggung jawab, disiplin, kesatuan perintah, kesatuan pengarahan, pengabdian untuk kepentingan umum, penggajian pegawai, pemusatan, hierarki, ketertiban dan keamanan, keadilan dan kejujuran, inisiatif, inovatif dan rasa kebersamaan.

Memperhatikan uraian di atas, maka penelitian ini akan berusaha mengungkapkan pentingnya 
kepemimpinan, kualitas SDM dan budaya organisasi terhadap optimalisasi kinerja pegawai Perpustakaan Nasional RI di Jakarta.

\section{B. Rumusan Masalah}

Berdasarkan latar belakang di atas maka permasalahan penelitian ini dirumuskan sebagai berikut: "Bagaimana pengaruh kepemimpinan, kualitas SDM dan budaya organisasi terhadap optimalisasi kinerja pegawai di Perpustakaan Nasional RI Jakarta".

\section{Tujuan Penelitian}

Memperhatikan rumusan masalah tersebut, maka tujuan yang ingin dicapai melalui penelitian ini adalah untuk mengetahui pengaruh kepemimpinan, kualitas SDM, dan budaya organisasi terhadap optimalisasi kinerja pegawai secara empiris dengan dukungan teori yang diperoleh selama mengikuti kuliah, membaca literatur dan memadukan dengan kenyataan obyektif yang ada di lapangan.

\section{Manfaat Penelitian}

Hasil penelitian ini diharapkan dapat memberikan manfaat sebagai berikut :

a. Untuk memberikan sumbangan pemikiran dan sekaligus bahan masukan kepada Perpustakaan Nasional RI untuk pengambilan kebijakan, menentukan keberadaan perpustakaan dalam memenuhi kebutuhan masyarakat pengguna informasi, dan senantiasa memperhatikan pentingnya kepemimpinan, kualitas SDM, dan budaya organisasi agar dapat memberikan kontribusi dalam upaya optimalisasi kinerja pegawai yang ada.

b. Sebagai rekomendasi untuk lebih mengoptimalkan kualitas kinerja Perpustakaan Nasional RI Jakarta dalam memenuhi kebutuhan masyarakat pengguna informasi. c. Menjadi literatur atau acuan untuk penelitian lebih lanjut tentang kepemimpinan, kualitas SDM, dan budaya organisasi terhadap optimalisasi kinerja pegawai.

\section{LANDASAN TEORI}

\section{A. Kepemimpinan}

Pemimpin pada hakekatnya laksana sebuah "lokomotif" yang akan membawa "gerbong-gerbong" organisasi. Modernitas organisasi telah membangkitkan kesadaran akan hakekat dan eksistensi kepemimpinan, bahkan dekade tarakhir ini dapat disebut era revolusi kepemimpinan. Tuntutan akan pemimpin yang profesional semakin terasa, sejalan dengan tuntutan akan hadirnya manusia organisasional yang semakin sadar bahwa sistem manajemen bergerak dari sifat amatiran menuju kematangan profesional yang dibarengi dengan faktor pendukung yang akurat. Dengan kata lain, pemimpin paling utama dituntut bagaimana mampu memberdayakan segala kekuatan organisasi secara benar dan tepat sesuaı dengan gelombang perubahan atau tantangan masa depan yang mempengaruhi kehidupan organisasi.

Kepemimpinan menurut Wahjosumidjo (2000: 176) adalah "Seni atau proses mempengaruhi orang lain, sedemikian rupa sehingga mereka mau melakukan usaha atau keinginan untuk bekerja dalam rangka pencapaian tujuan kelompok".

Konsep tersebut muncul suatu fenomena, bahwa seorang pemimpin adalah orang yang dikagumi oleh orang lain atau bawahan, sehingga ada kecenderungan untuk meniru apa yang dilakukan oleh pimpinannya.

Hakekat kepemimpinan adalah terletak pada kemampuan seorang pemimpin mengajak dan mempengaruhi pihak lain termasuk bawahan, untuk bekerja sama melakukan kegiatan tertentu dalam 
rangka merealisasi tujuan secara efektif dan efisien dalam suasana kerja yang menyenangkan (Favorable climate).

Manajemen yang baik adalah manajemen yang mampu menghasilkan keputusan-keputusan bermutu, baik kuantitatif maupun kualitatif. Tidak ada manajemen yang lebih baik, kecuali manajemen yang mampu meraih perubahan-perubahan positif, rasional, dan objektifitas bagi organisasi.

Sejalan dengan deskripsi kepemimpinan tersebut di atas, maka dalam melaksanakan aktivitas perpustakaan diperlukan kepemimpinan untuk memberikan arah dan menggerakkan semua potensi sumber daya yang ada dengan kemampuan melihat dan menyesuaikan perubahan zaman guna mencapai tujuan perpustakaan yang telah dirumuskan dalam visi dan misinya.

Pandangan teori ini Lumbatoruan (1990: 115), menyatakan bahwa gaya kepemimpinan dan manajemen harus disesuaikan dengan lingkungan dan situasi dalam organisasi. Oleh karena itu, keberhasilan suatu organisasi juga tergantung pada kemampuan pimpinan untuk menyesuaikan diri dengan ketentuanketentuan dan kondisi lingkungan dalam organisasi itu (Syihabuddin, 2003: 301).

\section{B. Kualitas SDM}

Perkembangan ilmu pengetahuan dan teknologi saat ini sangat besar pengaruhnya terhadap individu maupun organisasi dalam mengakses informasi. Fasilitas jaringan (network) nasional dan internasional berkembang dengan sangat pesat. Information superhigway yang dibangun diseluruh dunia dapat menghubungkan pemakai pada layanan informasi digital melalui jaringan telekomunikasi global. Hal ini berimbas pada cakupan kerja perpustakaan. Ragam akses ke layanan perpustakaan tidak lagi dibatasi oleh jarak dan waktu yang memungkinkan untuk banyak orang. Pengguna (users) akan semakin berharap banyak terhadap produktivitas, efisiensi dan efektivitas dalam akses untuk berbagai layanan perpustakaan.

Kondisi dari gambaran tersebut di atas menyiratkan adanya tuntutan terhadap dukungan kualitas SDM yang memadai. Sebab bagaimanapun canggihnya teknologi jika tidak diimbangi oleh dukungan kualitas SDM yang handal, tidak akan berarti apa-apa. Hal ini sejalan dengan pendapan Hasibuan (2005: 244) bahwa peralatan yang handal/canggih tanpa peran aktif SDM, tidak berarti apa-apa.

Hakekat SDM dalam suatu organisasi (perpustakaan) merupakan kunci yang akan menentukan keberhasilan organisasi. Karena SDM merupakan titik sentral dari penyelenggara seluruh fungsi-fungsi manajerial. Artinya bahwa teknik, gaya, dan mekanisme penyelenggara berbagai fungsi manajerial harus berangkat dan tiba pada pengakuan bahwa manusia merupakan unsur terpenting dalam seluruh proses manajerial tersebut.

Oleh karena itu keberadaan SDM dalam organisasi perlu mendapat perhatian khusus dengan memperhatihan manusia dari tiga sisi, menurut Sondang (2000:38-39), bahwa : a) manusia adalah mahluk yang mempunyai harkat dan martabat yang perlu dan harus dihargai; b) manusia dalam berkarya, ingin diperlakukan secara manusiawi; dan c) Manusia pekerja akan sangat senang apabila mereka diikutsertakan dalam proses pengambilan keputusan yang menyangkut kehidupan kekaryaannya melalui apa yang populer dengan istilah dan konsep pemberdayaan.

Sejalan dengan pendapat Supriyanto (1997: 156-157) bahwa "upaya perpustakaan dalam menghadapi masyarakat pengguna informasi sangat ditentukan oleh kemampuan SDM atau pengelola perpustakaan, pemanfaatan teknologi secara luas untuk memberikan tingkat layanan yang lebih luas serta 
adanya dukungan dari organisasi yang bersangkutan agar dapat menghadapi tantangan zaman."

SDM merupakan tulang punggung perpustakaan yang masih dapat dikembangkan lebih lanjut agar memiliki daya saing yang tinggi. Hal ini karena daya saing merupakan potensi terpenting yang harus dikembangkan pada diri setiap pegawai. Adanya peningkatan kualitas SDM akan berimplikasi pada optimalisasi kinerja pegawai, karena dengan pendidikan mereka akan memiliki wawasan yang lebih luas dan memiliki tanggung jawab yang lebih besar.

\section{Budaya organisasi}

Budaya organisasi (organizational culture) dalam suatu organisasi diyakini oleh para ilmuwan, perilaku organisasi dan manajemen serta sejumlah peneliti sebagai penentu keberhasilan atau kegagalan suatu organisasi. Karena budaya organisasi merupakan faktor penentu utama terhadap kesuksesan kinerja pegawai, dimana mengandung norma-norma, dan nilai-nilai yang dianut oleh semua yang terlibat di dalamnya. Hal ini sejalan dengan pendapat Luthans (1998) bakwa budaya organisasi merupakan normanorma dan nilai-nilai yang mengarahkan perilaku anggota organisasi. Sehingga setiap anggota akan berprilaku sesuai dengan budaya yang berlaku agar diterima oleh lingkungannya (Lako, 2004 : 29).

Gambaran ini dapat dikatakan bahwa budaya organisasi yang kuat, adaptif dan transformasional diyakini dapat berdampak positif terhadap optimalisasi kinerja pegawai dan keberhasilan organisasi baik dalam jangka pendek maupun dalam jangka panjang. Budaya organisasi yang kuat juga diyakini dapat berperan sebagai 1) variabel independen yang mempengaruhi praktik-praktik manajemen dan sikap pegawai, dan 2) sebagai variabel intern yang berperan mengkonseptualisasikan organisasi da lam pencapain visi, misi dan tujuan. Dengan kata lain budaya organisasi adalah mekanisme yang digunakan oleh suatu organisasi dan anggota-anggotanya untuk belajar mengelola tantangan-tantangan eksternal dan mewujudkan interaksi internal.

Perpustakaan Nasional RI sebagai salah satu Lembaga Pemerintah Non Departemen yang mempunyai peran dalam pemerintahan untuk melaksanakan tugas pemerintahan di bidang perpustakaan sesuai dengan undang-undang yang berlaku. Dengan melihat nilai-nilai fundamental dari budaya organisasi tersebut di atas, maka Perpustakaan Nasional dalam melaksanakan tugasnya dituntut agar dapat mengoptimalkan kinerjanya dengan dukungan nilai-nilai budaya tersebut.

\section{Optimalisasi Kinerja Pegawai}

Kinerja adalah gambaran mengenai tingkat kemampuan pencapaian pelaksanaan suatu kegiatan/ program/kebijakan dalam periode waktu tertentu berdasarkan tujuan dan sasaran yang telah ditentukan guna mewujudkan visi dan misi organisasi.

Optimalisasi adalah hasil yang dicapai menuntut agar penyelenggaraan operasional dalam organisasi didasarkan pada prinsip, atau paling sedikit pendekatan, efisiensi (daya guna) dan efektifitas (hasil guna) kinerja.

Istilah Kinerja berasal dari kata $J_{o b}$ Performance atau Actual Ferformance (prestasi kerja atau prestasi sesungguhnya yang dicapai oleh seseorang). Pengertian ini sama dengan apa yang disebutkan Mangkunegara (1995 : 45), sebagai hasil kerja secara kualitas dan kuantitas yang dicapai oleh seseorang dalam melaksanakan tugasnya sesuai dengan tanggung jawab yang diberikan kepadanya (Widodo, 2004 : 77).

Faktor-faktor yang mempengaruhi kinerja meliputi faktor kemampuan., faktor individu dan situasi, faktor motivasi dan faktor perilaku. Dengan kata lain faktor-faktor yang mempengaruhi kinerja seseorang, 
pada dasarnya terdiri dari individual variabel, situasional variabel, motivasi, kemampuan dan perilaku.

Sikap mental merupakan kondisi yang mendorong diri seseorang untuk mencapai prestasi kerja yang optimal. Oleh karena itu, sikap mental harus siap secara Psico Phois (siap secara mental, fisik, tujuan dan situasi) artinya, seorang pegawai harus siap mental, mampu secara fisik memahami tujuan utama dan target kerja yang akan dicapai, mampu memanfaatkan dan menciptakan situasi kerja.

\section{METODE PENELITIAN DAN HIPOTESIS}

\section{A. Metode Penelitian}

Penelitian ini menggunakan metode survei dengan analisis deskriptif melalui alat pengumpul data kuesioner yang dikumpulkan dari responden pada sampel yang mewakili populasi. Hal ini sesuai dengan pendapat Singarimbun (1995 : 3) bahwa penelitian survei adalah mengumpulkan data dari sampel yang mewakili populasi dengan menggunakan kuesioner.

Populasi penelitian ini adalah seluruh pegawai Perpustakaan Nasional RI. yang berjumlah 693 orang. Sedangkan populasi terjangkau adalah sebagian besar pegawai mulai dari eselon III, IV, fungsional dan seluruh staf.

Sampling adalah teknik pengambilan sampel dari semua anggota populasi dengan menggunakan teknik proporsional Random Sampling, yaitu teknik pengambilan sampel dari semua anggota populasi yang sebanding dengan besar setiap strata, Rakhmat ( 2004 :79). Hal ini sejalan dengan Widodo (2004:48) bahwa sampel proporsional (proportional) apabila karakteristik popolasi terdiri dari kategori, kelompok atau golongan yang setara atau sejajar. Dan oleh Burhan (2005 : 114) mengatatakan bahwa yang terpenting digunakan dalam teknik ini adalah penggunaan perwakilan berimbang, dengan mengetahui besar kecilnya unit-unit populasi yang ada.

Dalam penelitian ini besarnya sampel ditentukan sebanyak 120 responden, lebih banyak daripada persyaratan minimum yang dikemukakan oleh Singarimbun yang mendistribusikan sampel minimal sejumlah $>30$ kasus. Sehingga lebih besar tiga puluh kali lipat dari jumlah variabel yang diteliti, dalam hal ini jumlah variabel yang diteliti adalah 4 variabel, jadi $4 \times 30=120$ responden.

Selanjutnya dilakukan uji reliabilitas (keandalan) untuk mengukur koesioner sebagai indikator dari variabel. Kemudian dilakukan uji validitas untuk menentukan sah/valid tidaknya kuesioner yang digunakan. Pengukuran variabel kepemimpinan, kualitas SDM, budaya organisasi dan optimalisasi kinerja pegawai dianalisis dengan menggunakan teknik penskoran dengan skala model "Likert". Teknik analisis data menggunakan korelasi product moment. Adapun teknik analisis data dengan menggunakan program SPSS $(10,05)$ dan program Excel untuk menganalisis data statistik dengan pendekatan kuantitatif agar memperoleh hasil yang lebih akurat dan teruji. Hasil tersebut dianalisis melalui pendekatan kualitatif yaitu pemaknaan dan pembahasan lebih lanjut terhadap pengaruh variabel kepemimpinan, kualitas SDM, dan budaya organisasi terhadap optimalisasi kinerja pegawai.

\section{B. Hipotesis Penelitian}

Berdasarkan uraian latar belakang masalah, rumusan masalah, dan landasan teori di atas, maka hipotesis dalam pembahasan ini adalah :

1. Diduga ada pengaruh positif faktor kepemi mpinan $\left(X_{1}\right)$ terhadap optimalisasi kinerja pegawai Perpustakaan Nasional RI (Y). Artinya makin baik kepemimpinan diterapkan, maka optimalisasi kinerja pegawai di Perpustakaan Nasional RI semakin baik 
2. Diduga ada pengaruh positif faktor peningkatan kualitas SDM $\left(\mathrm{X}_{2}\right)$ terhadap optimalisasi kinerja pegawai di Perpustakaan Nasional RI (Y). Artinya makin tinggi kualitas SDM, maka optimalisasi kinerja pegawai semakin tinggi.

3. Diduga ada pengaruh positif faktor budaya organisasi $\left(\mathrm{X}_{3}\right)$ terhadap optimalisasi kinerja pegawai di Perpustakaan Nasional RI (Y). Artinya makin tinggi budaya organisasi, maka optimalisasi kinerja pegawai semakin tinggi.

4. Diduga ada pengaruh positif secara bersama-sama antara kepemimpinan $\left(\mathrm{X}_{1}\right)$, peningkatan kualitas $\operatorname{SDM}\left(\mathrm{X}_{2}\right)$ dengan budaya organisasi $\left(\mathrm{X}_{3}\right)$ dalam mendukung optimalisasi kinerja pegawai (Y) di Perpustakaan Nasional RI. Artinya Kepemimpinan, peningkatan kualitas SDM dan budaya organisasi secara bersama-sama memberikan kontribusi dalam meningkatkan optimalisasi kinerja pegawai.

\section{HASIL PENELITIAN \& PEMBAHASAN}

Data yang terkumpul dilakukan coding sheet berdasarkan variabel dan indikator, kemudian dilakukan pengujian reliabilitas, validitas dan analisis statistik deskriptif melalui program SPSS dan excel akan diperoleh nilai rata-rata atau rata-rata standar deviasi, nilai maksimum dan minimum, serta distribusi frekuensi dari masing-masing variable.

Deskripsi data secara lengkap hasil penelitian untuk variabel kepemimpinan $\left(\mathrm{X}_{1}\right)$, Kualitas $\operatorname{SDM}\left(\mathrm{X}_{2}\right)$, Budaya Organisasi
$\left(\mathrm{X}_{3}\right)$, dan Optimalisasi Kinerja (Y) disajikan pada tabel 1.

Berdasarkan pengukuran pada tabel di atas, secara hipotetik dan secara empiris data yang diperoleh dari hasil penelitian menunjukkan bahwa variabel kepemimpinan $\left(X_{1}\right)$ rataan empirik lebih besar daripada rataan hipotetik $(50,36>45,00)$, maka dapat diketahui bahwa kepemimpinan di Perpustakaan Nasional RI Jakarta secara umum baik.

Selanjutnya subjek secara hipotetik dan secara empiris untuk variabel kualitas $\operatorname{SDM}\left(\mathrm{X}_{2}\right)$ data yang diperoleh dari hasil penelitian menunjukkan bahwa rataan empirik lebih besar daripada rataan hipotetik $(50,29>45,00)$, maka dapat diketahui bahwa kualitas SDM di Perpustakaan Nasional RI Jakarta secara umum baik.

Kemudian subjek secara hipotetik dan secara empiris untuk variabel budaya organisasi $\left(\mathrm{X}_{3}\right)$ rataan empirik lebih besar daripada rataan hipotetik $(55,07>$ 48,00 ), maka dapat diketahui bahwa budaya organisasi di Perpustakaan Nasional RI Jakarta secara umum baik.

Terakhir subjek secara hipotetik dan secara empiris untuk variabel optimalisasi kinerja (Y) rataan empirik lebih besar daripada rataan hipotetik $(33,66>$ 27,00), maka dapat diketahui bahwa optimalisasi

Tabel 1: Deskripsi Data Penelitian

\begin{tabular}{|c|c|c|c|c|c|c|c|c|}
\hline \multirow{3}{*}{$\begin{array}{l}\text { Variabel } \\
(\mathrm{N}=120)\end{array}$} & \multicolumn{4}{|c|}{ Data Hipotetik } & \multicolumn{4}{|c|}{ Data Empirik } \\
\hline & \multicolumn{2}{|c|}{ Skor } & \multirow{2}{*}{ Mean } & \multirow{2}{*}{$S D$} & \multicolumn{2}{|c|}{ Skor } & \multirow{2}{*}{ Mean } & \multirow{2}{*}{ S D } \\
\hline & $\mathrm{M} \mathrm{ak}$ & $M$ in & & & M ak & $\mathrm{M}$ in. & & \\
\hline 1. Kepemimpinan & 75 & 15 & 45,00 & 10,00 & 73 & 24 & 50,36 & 9,90 \\
\hline 2. Kualitas SDM & 75 & 15 & 45,00 & 10,00 & 70 & 34 & 50,29 & 7,30 \\
\hline $\begin{array}{l}\text { 3. Budaya } \\
\text { Organisas } i\end{array}$ & 80 & 16 & 48,00 & 10,67 & 75 & 32 & 55,07 & 7,50 \\
\hline $\begin{array}{l}\text { 4. Optimalisasi } \\
\text { Kinerja }\end{array}$ & 45 & 9 & 27,00 & 6,00 & 45 & 24 & 33,66 & 4,08 \\
\hline
\end{tabular}


kinerja di Perpustakaan Nasional RI Jakarta secara umum baik

Arikunto (1997) menjelaskan bahwa penentuan kategori, dilakukan dengan membandingkan nilai-nilai setiap butir dengan rata-rata nilai semua butir sebagai pembatas. Nilai yang berada di atas nilai rata-rata menunjukkan kategori "tinggi", sedangkan nilai ratarata dan lebih rendah dari rata-rata menunjukkan kategori "rendah". Sejalan dengan Azwar (1992) bahwa kategorisasi dilakukan dengan menggolongkan 5 kategori subyek sehingga terdistribusi secara normal maka diperoleh kategorisasi serta distribusi frekuensi skor hasil penilaian responden sebagai berikut :

Tabel 2: Kepemimpinan di Perpustakaan Nasional RI Jakarta

\begin{tabular}{|c|c|c|c|}
\hline Skor & Kategorisasi & Frekuensi & Persentase \\
\hline $63 \leq x \leq 75$ & Sanga1 Tinggi & 9 & $7,50 \%$ \\
\hline $51<x<63$ & Tinggi & 50 & $41,66 \%$ \\
\hline $39 \leq x \leq 51$ & Cukup Tinggi & 47 & $39,17 \%$ \\
\hline $27<x<39$ & Rendah & 11 & $9,17 \%$ \\
\hline $15 \leq x \leq 27$ & Sangat Rendah & 3 & $2,50 \%$ \\
\hline Mean Empiris $=50,36$ & Total & 120 & $100,00 \%$ \\
\hline
\end{tabular}

dikategorikan sedang, dimana jawaban responden masih $50,84 \%$ atau rata-rata $50,36 \%$ berada pada kategori cukup tinggi.

Hal ini sejalan dengan pengamatan penulis mengenai fenomena kepemimpinan di Perpustakaan Nasional sudah berjalan dengan baik, namun masih perlu ditingkatkan karena belum sepenuhnya sesuai harapan di mana belum semua pimpinan pada tiaptiap unit/bagian bersikap tegas dalam melaksanakan keputusan dan perintah. Sedang tingkat komunikasi antar bawahan, unit/bagian lain juga masih ada yang menganggap kurang penting.

Untuk mengetahui ada pengaruh positif faktor kepemimpinan $\left(\mathrm{X}_{1}\right)$ terhadap optimalisasi kinerja pegawai (Y) menunjukkan signifikan di mana probabilitas sebesar 0,00 lebih kecil daripada 0,05 maka dapat diketahui bahwa koefisien regresi $\mathrm{X}_{1}$ terhadap $\mathrm{Y}$ signifikan pada taraf kepercayaan $95 \%$. Dan melalui nilai koefisien regresi dengan persamaan $\mathbf{Y}=$ $10,404+0,134 X_{1}$. Hal ini dapat dinterpretasi

1. Kepemimpinan. Hasil penilaian responden untuk mengetahui tinggi rendahnya tingkat kepemimpinan di Perpustakaan Nasional RI. apabila subjek digolongkan dalam 5 kategori, maka didapat kategorisasi serta distribusi frekuensi skor hasil penilaian responden seperti disajikan pada tabel 2.

Berdasarkan hasil jawaban responden di atas dapat dikategorikan bahwa jawaban cukup tinggi sampai dengan sangat rendah mencapai $50,84 \%$, sedangkan jawaban tinggi sampai dengan sangat tinggi hanya $49,16 \%$ dan nilai rata-rata empiris adalah $50,36 \%$ berada pada kategori cukup tinggi. Hal ini diasumsikan bahwa tingkat kepemimpinan di Perpustakaan Nasional RI masih perlu mendapat perhatian dan perlu ditingkatkan, karena masih
Tabel 3: Kualitas SDM di Perpustakaan Nasional RI Jakarta

\begin{tabular}{|c|c|c|c|}
\hline Skor & Kategorisasi & Frekuensi & Persentase \\
\hline $63 \leq \mathrm{x} \leq 75$ & Sangat Tinggi & 6 & $5,00 \%$ \\
\hline $51<\mathrm{x}<63$ & Tinggi & 45 & $37,50 \%$ \\
\hline $39 \leq \mathrm{x} \leq 51$ & Cukup Tinggi & 58 & $48,33 \%$ \\
\hline $27<\mathrm{x}<39$ & Rendah & 11 & $9,17 \%$ \\
\hline $15 \leq \mathrm{x} \leq 27$ & Sangat Rendah & 0 & $0,00 \%$ \\
\hline Mcan Empiris $=50,29$ & Tolal & 120 & $100,00 \%$ \\
\hline
\end{tabular}

Sumber: Pengolahan Data Primer dengan Perangkar Lunak Komputer 
2. Kualitas SDM. Hasil penilaian responden terhadap kualitas SDM apabila subjek digolongkan dalam 5 tingkatan/kategori disajikan pada tabel berikut.

Berdasarkan tabel di atas hasil jawaban responden walaupun cukup bervariasi, dapat dikategorikan bahwa jawaban cukup tinggi sampai dengan sangat rendah mencapai $57,50 \%$, sedangkan jawaban tinggi sampai dengan sangat tinggi hanya $42,50 \%$ dan nilai rata-rata empiris adalah $50,29 \%$ berada pada kategori cukup tinggi. Hal ini diasumsikan bahwa tingkat kualitas SDM di Perpustakaan Nasional RI masih perlu mendapat perhatian dan perlu ditingkatkan, karena masih dikategorikan rendah, dirnana jawaban responden masih $57,50 \%$ atau ratarata $50,29 \%$ berada pada kategori cukup tinggi.

Kondisi kualitas SDM yang ada jika diperhatikan dari tingkat pendidikan pegawai Perpustakaan Nasional secara umum masih perlu ditingkatkan karena yang berpendidikan Sekolah Dasar sampai dengan Sarjana Muda masih terdapat 55,27\% sedangkan Sarjana dan Pasca Sarjana hanya 44,73\%. Selain itu upaya untuk memperoleh kualitas SDM yang berkompetensi pada masing-masing pekerjaan, bukan hanya melalui pendidikan formal tetapi juga melalui pendidikan non formal (pendidikan teknis) seperti diklat, kursus, magang, dan lain lain disesuaikan dengan tuntutan tugas dan mengikuti seminar-seminar guna memperluas wawasan dan dilaksanakan secara berkesinambungan.

Untuk mengetahui ada pengaruh positif faktor kualitas SDM $\left(\mathrm{X}_{2}\right)$ terhadap optimalisasi kinerja pegawai (Y) menunjukkan pada signifikan di mana probabilitas sebesar 0,03 lebih kecil daripada 0,05 maka dapat diketahui bahwa koefisien regresi $\mathrm{X}_{2}$ terhadap $\mathrm{Y}$ signifikan pada taraf kepercayaan $95 \%$. Dan melalui nilai koefisien regresi dengan persamaan $Y=\mathbf{1 0 , 4 0 4}$ $+\mathbf{0 , 1 4 6} \mathrm{X}_{2}$. Hal ini dapat diinterpretasi bahwa kenaikan skor $X_{2}$ sebesar 1 satuan akan menaikkan variabel $Y$ sebesar 0,146 satuan. Artinya optimalisasi kinerja pegawai di Perpustakaan Nasional akan meningkat sebesar 14,6\% jika faktor kualitas SDM ditingkatkan 1 satuan. Dengan demikian hipotesis kedua penelitian ini dapat diterima.

3. Budaya Organisasi. Hasil penilaian responden terhadap budaya organisasi apabila subjek digolongkan dalam 5 tingkatan/kategori disajikan pada tabel 4.

Dengan memperhatikan hasil jawaban responden pada tabel di atas, dapat dikategorikan bahwa jawaban cukup tinggi sampai dengan sangat rendah masih terdapat $49,16 \%$, sedangkan jawaban tinggi sampai dengan sangat tinggi mencapai 50,84\% dan nilai rata-rata empiris adalah $55,07 \%$ berada pada kategori tinggi. Hal ini diasumsikan bahwa tingkat budaya organisasi di Perpustakaan Nasional RI sudah berjalan dengan baik, namun perlu dijaga dan dipelihara terus menerus dimana jawaban responden menunjukkan $50,84 \%$ dan rata-rata $55,07 \%$ berada pada kategori tinggi. Dan masih terdapat $49,16 \%$ yang perlu mendapat perhatian.

Kondisi ini menurut penulis walaupun sudah menggambarkan baik, namun perlu diingat bahwa budaya organisasi memiliki pengaruh yang kuat terhadap kebiasaan, sikap dan tingkah laku bagi setiap yang terlibat di dalam organisasi. Kebiasaan, sikap dan tingkah laku tersebut dapat berubah sewaktu-waktu
Tabel 4: Budaya Organisasi di Perpustakaan Nasional RI Jakarta

\begin{tabular}{|c|c|c|c|}
\hline Skor & Kategorisasi & Frekuensi & Persentase \\
\hline $67,2 \leq x \leq 80,0$ & Sangat Tinggi & 7 & $5,84 \%$ \\
\hline $54,4<x<67,2$ & Tinggi & 54 & $45,00 \%$ \\
\hline $41,6 \leq x \leq 54,4$ & Cukup Tinggi & 55 & $45,83 \%$ \\
\hline $28,8<\mathrm{x}<41,6$ & Rendah & 4 & $3,33 \%$ \\
\hline $16 \leq \mathrm{x} \leq 28,8$ & Sangat Rendah & 0 & $0,00 \%$ \\
\hline Mean Empiris $=55,07$ & Total & 120 & $100,00 \%$ \\
\hline
\end{tabular}

Sumber: Pengolahan Data Primerdengan Perangkat Lunak Komputer 
pada diri pribadi dan dapat mempengaruhi orang lain. Suatu aturan yang berlaku dapat berjalan dengan baik jika dipahami dan dilaksanakan oleh setiap orang. Dan sebaliknya tidak akan berjalan jika tidak dipahami dan dilaksanakan oleh semua atau sebagian orang saja.

Untuk mengetahui ada pengaruh positif faktor budaya organisasi $\left(\mathrm{X}_{3}\right)$ terhadap optimalisasi kinerja pegawai (Y) pada signifikan di mana probabilitas sebesar 0,01 lebih kecil daripada 0,05 maka dapat diketahui bahwa koefisien regresi $X_{3}$ terhadap $Y$ signifikan pada taraf kepercayaan $95 \%$. Dan melalui nilai koefisien regresi dengan persamaan $Y=\mathbf{1 0 , 4 0 4}$

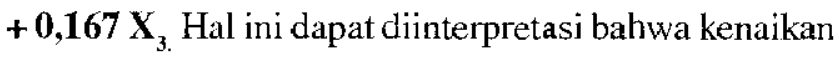
skor $\mathrm{X}_{3}$ sebesar 1 satuan akan menaikkan variabel $\mathrm{Y}$ sebesar 0,167 satuan. Dengan kata lain optimalisasi kinerja pegawai di Perpustakaan Nasional akan meningkat sebesar $16,7 \%$ jika faktor budaya organisasi ditingkatkan 1 satuan. Dengan demikian hipotesis ketiga dapat diterima.

Gambaran dari fenomena yang sering terjadi misalnya kinerja pegawai sangat ditentukan oleh tingkat disiplin pegawai. Dari pengamatan penulis selama ini tingkat kedisiplinan pegawai (disiplin jam kerja dan disiplin dalam menyelesaikan tugas) di Perpustakaan Nasional masih belum sesuai dengan harapan. Hal ini sering pula menjadi topik pembicaraan pimpinan dalam setiap rapat pertemuan, dan perayaan Hari Nasional bahwa tingkat disiplin pegawai masih belum sesuai dengan harapan.

Pengamatan penulis, kondisi ini merupakan suatu kebiasaan yang terkadang dipahami oleh pegawai sebagai suatu hal biasa, sehingga walaupun menyalahi suatu aturan disiplin pegawai dianggap tidak terlalu penting. Pada hal Tabel 5 : Optimalisasi Kinerja di Perpustakaan Nasional RI Jakarta

\begin{tabular}{|c|c|c|r|}
\hline Skor & Kategorisasi & Frekuensi & Persentase \\
\hline $37,8 \leq \mathrm{x} \leq 45,0$ & Sangat Tinggi & 18 & $15,00 \%$ \\
\hline $30,6<\mathrm{x}<37,8$ & Tinggi & 81 & $67,50 \%$ \\
\hline $23,4 \leq \mathrm{x} \leq 30,6$ & Cukup Tinggi & 21 & $17,50 \%$ \\
\hline $16,2<\mathrm{x}<23,4$ & Rendah & 0 & $0,00 \%$ \\
\hline $9 \leq \mathrm{x} \leq 16,2$ & Sangat Rendah & 0 & $0,00 \%$ \\
\hline Mean Empiris=33,66 & Total & 120 & $100,00 \%$ \\
\hline
\end{tabular}
kondisi ini jika berlangsung terus akan berpengaruh terhadap rendahnya kinerja pegawai. Oleh karena itu untuk mengatasi fenomena tersebut budaya organisasi hendaknya dipahami dan dilaksanakan oleh semua pegawai. Karena jika ada sebagian pegawai yang tidak memahami dan melaksanakan akan mempengaruhi kinerja pegawai pada tiap pekerjaan/unit /bagian lain yang akhirnya mempengaruhi kinerja keseluruhan.

4. Optimalisasi Kinerja. Hasil penilaian responden terhadap optimalisasi kinerja organisasi apabila subjek digolongkan dalam 5 tingkatan/kategori disajikan pada tabel 5 .

Berdasarkan hasil jawaban responden pada tabel di atas, dapat dikategorikan bahwa jawaban cukup tinggi masih terdapat $17,50 \%$, sedangkan rendah sampai dengan sangat rendah tidak ada. Kemudian jawaban tinggi sampai dengan sangat tinggi mencapai $80,50 \%$ dan nilai rata-rata empiris adalah $33,66 \%$ berada pada kategori tinggi. Hal ini diasumsikan bahwa optimalisasi kinerja pegawai di Perpustakaan Nasional RI sudah berjalan dengan baik, namun perlu dijaga dan dipelihara terus menerus di mana jawaban responden masih terdapat $17,50 \%$ yang perlu mendapat perhatian. Sedangkan $80,50 \%$ dan ratarata $33,66 \%$ berada pada kategori tinggi.

Sehubungan dengan adanya perbedaan jawaban responden dengan pengamatan penulis selama ini, dimana penenulis masih sering melihat terjadi keterlambatan dalam penyelesaian program 
kerja pada unit-unit kerja, sehingga belum mencapai sasaran sesuai dengan yang diharapkan. Kondisi ini menggambarkan bahwa upaya mengoptimalkan kinerja pegawai di Perpustakaan Nasional RI masih perlu mendapat perhatian dan perlu ditingkatkan agar program kerja dapat diselesaikan tepat waktu.

\section{Hubungan antara Kepemimpinan, Kualitas SDM, dan Budaya Organisasi Terhadap Optimalisasi Kinerja Pegawai}

Penelitian ini lebih lanjut menggambarkan hubungan yang kuat antara tiga variabel bebas yaitu $\mathrm{X}_{1}, \mathrm{X}_{2}$, dan $\mathrm{X}_{3}$ dengan variabel terikat $\mathrm{Y}$ berdasarkan hasil uji $F_{\text {liturg }}$ sebesar 64,981 maka dapat diketahui bahwa hipotesis keempat penelitian ini yang menyatakan ada pengaruh serentak darj variabel $X_{1}$, $\mathrm{X}_{2}$, dan $\mathrm{X}_{3}$ terhadap variabel $\mathrm{Y}$ terbukti dengan meyakinkan.

Selanjutnya ketiga faktor tersebut dapat dilihat bahwa variabel budaya organisasi ternyata mempunyai pengaruh yang paling dominan terhadap optimalisasi kinerja pegawai jika dibandingkan dengan variabel kepemimpinan dan variabel kualitas SDM. Hal ini berdasarkan hasil pengujian dan telah dijelaskan di atas.

\section{KESIMPULAN DAN SARAN}

\section{A. Kesimpulan}

Berdasarkan hasil analisis dan pembahasan data sebagaimana yang diuraikan di atas, dapat disimpulkan sebagai berikut :

1. Terdapat pengaruh positif yang signifikan antara kepemimpinan dengan optimalisasi kinerja pegawai. Pengujian dibuktikan dengan melihat hubungan variabel $X_{1}$ melalui nilai koefisien $\hat{a}_{1}$ adalah 0,134 dengan persamaan $Y=\mathbf{1 0 , 4 0 4}$ $+\mathbf{0 , 1 3 4} \mathrm{X}_{\mathbf{1}}$. Artinya optimalisasi kinerja pegawai di Perpustakaan Nasional akan meningkat sebesar 13,4\% jika faktor kepemimpinan ditingkatkan 1 satuan.

2. Terdapat pengaruh positif yang signifikan antara kualitas SDM dengan optimalisasi kinerja pegawai. Pengujian dibuktikan dengan melihat hubungan variabel $\mathrm{X}_{2}$ melalui nilai koefisien $\hat{\mathrm{a}}_{2}$ adalah 0,146 dengan persamaan $Y=\mathbf{1 0 , 4 0 4}+\mathbf{0 , 1 4 6}$ $\mathbf{X}_{2}$. Artinya optimalisasi kinerja pegawai di Perpustakaan Nasional akan meningkat sebesar $16,7 \%$ jika faktor budaya organisasi ditingkatkan 1 satuan.

3. Terdapat pengaruh positif yang signifikan antara budaya organisasi dengan optimalisasi kinerja pegawai. Pengujian dibuktikan dengan melihat hubungan variabel $\mathrm{X}_{3}$ melalui nilai koefisien $\hat{\mathbf{a}}_{3}$ adalah 0,167 dengan persamaan $Y=\mathbf{1 0 , 4 0 4 +}$

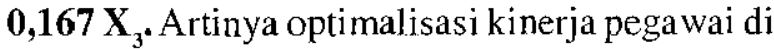
Perpustakaan Nasional akan meningkat sebesar $16,7 \%$ jika faktor budaya organisasi ditingkatkan 1 satuan

4. Terdapat pengaruh positif yang signifikan antara kepemimpinan, kualitas SDM, dan budaya organisasi secara bersama-sama terhadap optimalisasi kinerja pegawai. Hal ini menunjukkan bahwa jika kepemimpinan, kualitas SDM dan budaya organisasi secara bersama-sama ditingkatkan, maka optimalisasi kinerja pegawai akan meningkat pula. Selanjutnya dapat diinterpretasikan bahwa optimalisasi kinerja pegawai dapat dipengaruhi oleh faktor kepemimpinan, kualitas SDM dan budaya organisasi sebesar $65 \%$ sedangkan sisanya $35 \%$ dipengaruhi oleh faktor lain seperti kenaikan pangkat, motivasi, kesejahteraan dan lain-lain. Dengan demikian ketiga variabel bebas yang dipilih dalam penelitian ini, yaitu kepemimpinan, kualitas SDM, dan budaya organisasi mampu 
mempengaruhi tingkat optimalisasi kinerja pegawai, dimana $X_{3}$ mempunyai nilai yang paling berpengaruh, disusul $\mathrm{X}_{2}$, kemudian $\mathrm{X}_{1}$.

Perhitungan melalui pembuktian hipotesis keempat variabel yang diuji tersebut diatas, semua menunjukkan adanya pengaruh yang positif dan signifikan, sehingga hasil penelitian tersebut dapat digeneralisasikan atau diberlakukan kepada seluruh pegawai di Perpustakaan Nasional sebagai populasi.

\section{B.Saran-saran}

Berdasarkan hasil pembahasan dan kesimpulan di atas, maka diajukan beberapa saran sebagai bahan pemikiran dan masukan untuk meningkatkan kepemimpinan, kualitas SDM, dan budaya organisasi dalam upaya meningkatkan optimalisasi kinerja pegawai di Perpustakaan Nasional RI sebagai berikut:

1. Agar upaya meningkatkan dan mempertahankan kinerja pegawai di Perpusatakaan Nasional dapat terwujud, maka pimpinan pada tiap-tiap un it kerja diharapkan dapat berperan aktif, berlaku demokratis dengan menyesuaikan kondisi lingkungan kerja, melakukan komunikasi secara dua arah baik menyangkut tugas maupun komunikasi antar pribadi, dan memiliki sensitivis kepada kebutuhan para pegawai, baik kebutuhan individu maupun kebutuhan dalam pelaksanaan tugas sehingga semua pegawai dapat bekerja dengan baik guna memberikan kontribusi kepada kemajuan organisasi.

2. Untuk mewujudkan kualitas SDM yang handal sesuai kebutuhan organisasi, maka hendaknya dilakukan melalui rekruitmen pegawai yang sesuai kompetensi kebutuhan pekerjaan pada tiap-tiap unit kerja, didukung dengan mempersiapkan analisis kebutuhan (Job Description), dan peta kemampuan pegawai, meningkatkan kualitas SDM melalui pendidikan formal maupun non formal, dan menindaklanjuti penempatan pegawai yang disesuaikan dengan tingkat pendidikan yang dimiliki.

3. Budaya organisasi merupakan salah satu faktor yang sangat menentukan dalam upaya mengoptimalkan kinerja pegawai, maka Perpustakaan Nasional RI diharapkan dapat menciptakan suasana kerja yang kondusif, dengan menciptakan kerjasama yang kondusif antar unit kerja, meningkatkan disiplin kerja pegawai, pengakuan terhadap hasil kerja dengan berupaya memberikan reward, meningkatkan kesejahteraan, dan memberikan dorongan untuk meningkatkan diri serta menyederhanakan metode kerja, sehingga tidak berbelit-belit.

\section{DAFTAR PUSTAKA}

Arikunto, Suharsimi. 1997. Prosedur Penelitian : Suatu Pendekatan Prakti. Rimba Cipta : Jakarta.

Azwar, S. 1992. Reliabilitas dan Validitas. Sigma Alpha : Yogyakarta.

Bungin, H. M. Burhan, 2005. Metodologi Penelitian Kuantitatif : Komunikasi, Ekonomi, san Kebijakan Publik serta Ilmu-Ilmu Sosial lainnya. Prenada Media : Jakarta.

Hasibuan, Malayu S.P. 2005. Manajemen Sumber Daya Manusia. Bumi Aksara : Jakarta.

Lako, Andreas, 2004. Kepemimpinan dan Kinerja Organisasi : Isu, Teori, dan Solusi. Amara Books Yogyakarta. 
Mangkunegara, Anwar Prabu 1995. Manajemen Sumber Daya Manausia Perusahaan. Remaja Rosdakarya Bandung.

Qalyubi Syihabuddin, 2003. Dasar-Dasar Ilmu Perpustakaan dan Informasi. Jurusan ilmu Perpustakaan dan Informasi : Yogyakarta.

Rakhmat, Jalaluddin. 2004. Metode Penelitian Komunikasi. Remaja Rosdakarya : Bandung.

Singarimbun, Masri dan Sofian Effendi, 1995. Metode Penelitian Survai. Jakarta : LP3ES.

Siagian, Sondang P., 2000. Sistem Informasi Manajemen. Bumi Aksara : Jakarta.

Sugiyono. 2000. Metodologi Penelitian Bisnis. Alfabeta : Jakarta.

Wahjosumidjo. 2000. Teori Kepemimpinan dan Dasar-dasar Manajemen. Lembaga Administrasi Negara : Jakarta

Widodo, 2004. Cerdik Menyusun Proposal Penelitian Skripsi, Tesis, dan Disertasi : Dilengkapi Contoh. Yayasan Kelopak : Jakarta.

Undang-Undang RI Nomor 43 Tahun 1999 tentang Perubahan Undang-Undang Nomor 8 Tahun 1974 tentang Pokok-Pokok Kepegawaian. Mini Jaya Abadi : Jakarta. 